217

Received: March 15, 2016

Accepted: May 30, 2016

\title{
COMPARATIVE ANALYSIS OF HEMATOLOGICAL PARAMETERS IN WORKING POLICE DOGS
}

\author{
Damir Suljević $^{1}$, Muhamed Fočak ${ }^{1}$, Dunja Rukavina ${ }^{2}$, Amir Zahirović ${ }^{3}$ \\ ${ }^{1}$ Department for Biology, Faculty of Science, \\ Zmaja od Bosne 33-35, 71000 Sarajevo, Bosnia and Herzegovina \\ ${ }^{2}$ Department for Biology, Veterinary Faculty, Zmaja od Bosne 90, 71000 Sarajevo, Bosnia and Herzegovina, \\ ${ }^{4}$ Department for Internal Diseases, Veterinary faculty, \\ Zmaja od Bosne 90, 71000 Sarajevo, Bosnia and Herzegovina \\ mfocak10@gmail.com
}

\begin{abstract}
Hematological parameters were analyzed in working police dogs. The analysis of hematological parameters included three dog breeds: Belgian Shepherd dogs-Malinois $(n=27)$, Labrador Retriever $(n=54)$ and German Shepherd $(n=55)$, fifteen months to 10 years old. Training excercises affects their hematological parameters distinctly when comparing different dog breeds. Statistical analysis showed significant values for packed cell volume values $(p$ $=0.01)$, hemoglobin concentration $(p=0.00)$ and reticulocytes $(p=0.01)$ between compared breeds. In group from 2 to 7 years statistically significant differencies were obtained for packed cell volume $(p=0.00)$, hemoglobin concentration $(p=0.00)$ and reticulocytes $(p=0.003)$. Similar hematological values between Malinois and Labrador Retriever were obtained, and it can be concluded that German Shepherd dog can conduct more intensive trainings than Malinois or Labrador Retriever dogs. The obtained results enables the establishment of hematological and biochemical reference values in these three dogs blood breeds that will support clinical diagnosis and further research into working police dog physiology.
\end{abstract}

Key words: working dogs; hematological parameters; Malinois; German Shepherd; Labrador Retriever

\section{КОМПАРАТИВНА АНАЛИЗА НА ХЕМАТОЛОШКИТЕ ПАРАМЕТРИ КАЈ РАБОТНИ ПОЛИЦИСКИ КУЧИЫА}

\begin{abstract}
Анализирани се хематолошките параметри кај службени полициски кучиња. Анализата на хематолошките параметри вклучуваше три раси на кучиња: белгиски овчар-малиноа $(n=27)$, лабрадор ретривер $(n=54)$ и германски овчар $(n=55)$, на возраст од 15 месеци до 10 години. Тренинзите значајно влијаат на вредноста на хематолошките параметри при споредба на различните раси на кучиња. Статистичката анализа покажа значајни вредности за хематокритот $(p=0,01)$, концентрацијата на хемоглобинот $(p=0,00)$ и вредноста на ретикулоцитите $(p=0,01)$ кај расите. Во групата од 2 до 7 години возраст, се добиени статистички значајни разлики за вредноста на хематокритот $(p=0,00)$, концентрацијата на хемоглобинот $(p=0,00)$ и вредноста на ретикулоцитите $(p=0,003)$. Воочени се слични вредности на хематолошките параметри помеѓу малиноа и лабрадор ретривер, додека германскиот овчар врз основа на анализираните вредности може да издржи поинтензивни тренинзи во споредба со претходните две раси. Добиените резултати овозможуваат воспоставување на референтни вредности на хематолошките и биохемиските параметри во крвта кај овие три раси, а што е уште позначајно, и за воспоставување клиничка дијагноза и идни истражувања на физиологијата на работните полициски кучиња.
\end{abstract}

Клучни зборови: работни кучиња; хематолошки параметри; малиноа; германски овчар; лабрадор ретривер

\section{INTRODUCTION}

It is known that full-training can provoke different physiological and biochemical changes, de- pending on the types of physical excercises. The importance of dog sports increase scientific researches and reports about hematological parameters in training or working dogs. Knowledge 
about specific breed changes, it is important for defining individual training protocols, different diet, reduce training and other related disorders such as exhaustion, dehydration and heat stroke (Rovira et al. [1]). Athletic and working dogs usually perform activities and tasks with consumption high quantities of energy, more than average energy demand. Certain dog breeds are known for their ability to perform physical activities with minimal metabolic requrements. Working dogs have different metabolic requirements, compared with pet dogs. The heart rate increases to 115-240 beats per minute during training (Angle et al. [2]). Initial training can induce stress reactions. Metabolic stress changes can cause hyperglycemia, but hematological profile includes lymphopenia and eosinopenia, as well as neutronphilia and monocitosis (Otto et al. [3]). Cardiac rhythm is considered as a significant indicator of a relative cardiovascular activity and is used for monitoring training intensity and indicator of subclinical disease and pain (Foreman et al. [4]). The most important biochemical intermediate parameters during exercise is lactate, as indicator of fatigue (Cannon et al. [5]). Biochemical and hematological parameters are very important for the assessment of health and nutrition in dogs. There are numerous literature reports for reference values of blood parameters (Jensen et al. [6]).

The aim of this study was to analyze hematological parameters in different breeds of working police dogs after intensive training.

\section{EXPERIMENTAL SECTION}

Hematological analyses are usual for clinically healthy working police dogs, every year as a routine control of their health status. Three dogs breeds (males) were included in the research: German Shepherd dog $(n=55)$, Labrador Retriever ( $n$ $=54)$ and Malinois $(n=27)$ dogs, with ages form 15 months to 10 years old. All animals were treated in accordance with the "Declaration on the Rights of Animals" (UNESCO, 1978) and "Universal Declaration on Animal Welfare" (WSPA, 2000). Blood samples were collected from $v$. cephalica antebrachi externa and immediately placed EDTA tube. The values of hematological parameters were performed in the laboratory at internal diseases on the Veterinary Faculty in Sarajevo. Hematological analysis were done by an autoanalyzer VetLab Station LaserCyte, IDEXX (Netherlands). Obatined results were processed by descriptive and analytical statistics. Results were analyzed by using SPSS Version 17.0. software for estimation: mean values of different hematological parameters and statistically significant difference in all above mentioned parameters with regard to factors supposed to cause variation. About 95\% confidence interval and 5\% absolute percision were used through the research. PostHoc multiple tests (Tukey HSD) were also done, for the detection of pairs of groups between which the differences are significant. Hematological parameters included packed cell volume (PCV, \%), hemoglobin concentration $(\mathrm{Hb}, \mathrm{g} / \mathrm{l})$, mean corpuscular hemoglobin concentration ( $\mathrm{MCHC}, \mathrm{g} / \mathrm{dl}$ ) and white blood cells (WBC, 10\% $/ 1$ ). Differential blood count included absolute number of neutrophils (NEU, $10^{9} / 1$ ), eosinophils (EOS, $10^{9} / 1$ ) and lymphocytes (LYM, $\left.10^{9} / 1\right)$. Relative number of reticulocytes (RET, \%), platelets (PLT, 10\% $/ 1$ ) were also obtained.

\section{RESULTS AND DISCUSSION}

Results are presented in Table 1. Mean values of hemoglobin concentration, neutrophils, eosinophils, platelet and reticulocytes show variations between compared dog breeds.

Analysis of hematological parameters shows the greatest similarities between Labrador Retriever and Malinois dogs. Packed cell volume (PCV) showed wide range of individual values. The highest concentration of hemoglobin was observed in German Shepherd dog (193 g/l), while the lowest concentration was noticed in Labrador Retriever dogs $(111 \mathrm{~g} / \mathrm{l})$. Statistical analysis showed significant differencies for values of PCV $(p=0.01)$, hemoglobin concentration $(p=0.00)$ and reticulocytes $(p=0.01)$ between compared breeds using ANOVA. PostHoc test for significant hematological parameters (PCV, $\mathrm{Hb}$ and RET) showed differencies between Labrador Retriever and Malinois, as well as Malinois and German Shepherd dogs.

Breeds were divided in three groups by their age (1-2 years, 2-7 years and more than 7 years). Values of hematological analysis for these groups of dogs are presented in Table 2.

The bigest number of dogs were covered in group 2-7 years. The most hematological parameters were in reference range, except eosinophils and reticulocytes. White blood cells and neutronphils decreases in three breeds by aging. Values for 
platelets number is the highest during adolescence in Malinois and German Shepherd dogs, while lymphocytes number was the highest in Labrador Retriever and German Shepherd puppy dogs.

Table 1

Means $\pm S D$ and range of some hematological parameters in dogs

\begin{tabular}{|c|c|c|c|c|c|c|c|c|c|}
\hline Breed & $\begin{array}{c}\text { PCV } \\
(\%)\end{array}$ & $\begin{array}{l}\mathrm{Hb} \\
(\mathrm{g} / \mathrm{l})\end{array}$ & $\begin{array}{l}\text { MCHC } \\
(\mathrm{g} / \mathrm{dl})\end{array}$ & $\begin{array}{l}\text { WBC } \\
\left(10^{9} / 1\right)\end{array}$ & $\begin{array}{l}\text { NEU } \\
\left(10^{9} / 1\right)\end{array}$ & $\begin{array}{l}\text { EOS } \\
\left(10^{9} / 1\right)\end{array}$ & $\begin{array}{l}\text { LYM } \\
\left(10^{9} / 1\right)\end{array}$ & $\begin{array}{l}\text { PLT } \\
\left(10^{9} / 1\right)\end{array}$ & $\begin{array}{l}\text { RET } \\
(\%)\end{array}$ \\
\hline 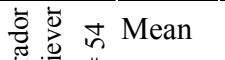 & $44 \pm 4^{\mathrm{a}}$ & $150.05 \pm 13.59^{\mathrm{a}}$ & $33.64 \pm 1.14$ & $11.58 \pm 3.35$ & $8.26 \pm 3.81$ & $1.32 \pm 0.57$ & $2.61 \pm 1.15$ & $360.51 \pm 126.7$ & $0.56 \pm 0.34^{\mathrm{a}}$ \\
\hline$\frac{0}{a}=$ Range & $33-52$ & $111.00-175.0$ & $29.30-36.2$ & $5.90-19.80$ & $4.00-24.8$ & $0.50-3.20$ & $1.40-6.50$ & $55.00-652.0$ & $0.20-1.80$ \\
\hline$\stackrel{n}{\stackrel{0}{\approx}}$ Mean & $46 \pm 3^{b}$ & $155.25 \pm 13.21^{\mathrm{b}}$ & $33.61 \pm 1.31$ & $11.51 \pm 3.30$ & $8.18 \pm 3.14$ & $1.39 \pm 0.64$ & $2.39 \pm 1.04$ & $346.55 \pm 149.2$ & $0.45 \pm 0.19^{b}$ \\
\hline$\sum_{\Sigma}^{\pi}=$ Range & $39-53$ & $126.00-181.0$ & $31.30-36.4$ & $6.00-18.60$ & $3.30-16.3$ & $0.60-2.50$ & $1.20-6.50$ & $14.00-627$ & $0.20-0.80$ \\
\hline 胥棺 Mean & $47 \pm 5^{\mathrm{a}}$ & $163.07 \pm 18.40^{\mathrm{a}}$ & $34.14 \pm 1.53$ & $10.87 \pm 2.62$ & $7.11 \pm 2.25$ & $2.20 \pm 3.08$ & $2.26 \pm 0.83$ & $336.85 \pm 109.9$ & $0.34 \pm 0.13^{\mathrm{a}}$ \\
\hline$\vec{D}=$ Range & $37-57$ & $111.00-193.0$ & $28.60-36.8$ & $5.30-16.60$ & $2.80-13.3$ & $0.60-22.0$ & $0.60-4.90$ & $20.00-642.0$ & $0.20-0.70$ \\
\hline Reference range & $37-55$ & $120-180$ & $30-37.5$ & $5.50-16.90$ & $2-12$ & $0.10-1.49$ & $0.50-4.90$ & $175-500$ & $0.01-0.11$ \\
\hline ANOVA Sig. & $0.01^{*}$ & $0.00^{*}$ & 0.09 & 0.44 & 0.12 & 0.15 & 0.19 & 0.61 & $0.017^{*}$ \\
\hline
\end{tabular}

*Statistically significant difference between dog breeds.

${ }^{\mathrm{ab}}$ Values in the same column for the same parameter which does not contain common letter mark have present statistical differencies.

Table 2

Means $\pm S D$ of hematological parameters in different age groups of dogs

\begin{tabular}{|c|c|c|c|c|c|c|c|c|c|c|}
\hline $\begin{array}{l}\overrightarrow{0} \\
\stackrel{0}{0} \\
\end{array}$ & Age & $\begin{array}{c}\text { PVC } \\
(\%)\end{array}$ & $\begin{array}{l}\mathrm{Hb} \\
(\mathrm{g} / \mathrm{l})\end{array}$ & $\begin{array}{c}\mathrm{MCHC} \\
(\mathrm{g} / \mathrm{dl})\end{array}$ & $\begin{array}{c}\text { WBC } \\
\left(10^{9} / 1\right) \\
\end{array}$ & $\begin{array}{c}\text { NEU } \\
\left(10^{9} / 1\right) \\
\end{array}$ & $\begin{array}{c}\text { EOS } \\
\left(10^{9} / 1\right)\end{array}$ & $\begin{array}{l}\text { LYM } \\
\left(10^{9} / 1\right)\end{array}$ & $\begin{array}{c}\text { PLT } \\
\left(10^{9} / 1\right) \\
\end{array}$ & $\begin{array}{c}\text { RET } \\
(\%)\end{array}$ \\
\hline \multirow{3}{*}{ 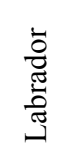 } & & $45 \pm 2$ & $155.00 \pm 7.81$ & $34.30 \pm 0.56$ & $10.90 \pm 1.78$ & $7.57 \pm 3.41$ & - & $3.33 \pm 1.88$ & $331.00 \pm 57.66$ & - \\
\hline & $2-7$ & $44 \pm 5^{\mathrm{a}}$ & $148.91 \pm 14.75^{\mathrm{a}}$ & $33.42 \pm 1.16$ & $11.76 \pm 3.29$ & $8.72 \pm 4.27$ & $1.46 \pm 0.62$ & $2.51 \pm 0.84$ & $366.26 \pm 125.53$ & $0.70 \pm 0.40^{\mathrm{a}}$ \\
\hline & $>7$ & $45 \pm 4$ & $151.47 \pm 12.57$ & $33.99 \pm 1.14$ & $11.34 \pm 3.89$ & $7.46 \pm 2.97$ & $0.98 \pm 0.31$ & $2.71 \pm 1.58$ & $354.24 \pm 145.06$ & $0.39 \pm 0.18$ \\
\hline \multirow{3}{*}{$\frac{\sqrt[n]{0}}{\stackrel{\Xi}{\Xi}}$} & $1-2$ & $45 \pm 1$ & $148.80 \pm 7.79$ & $33.24 \pm 1.34$ & $11.80 \pm 3.44$ & $8.24 \pm 3.54$ & $1.73 \pm 0.68$ & $2.18 \pm 0.31$ & $403.40 \pm 132.47$ & - \\
\hline & $2-7$ & $47 \pm 4^{b}$ & $157.71 \pm 15.67^{\mathrm{b}}$ & $33.81 \pm 1.44$ & $12.00 \pm 3.46$ & $8.54 \pm 3.31$ & $1.35 \pm 0.68$ & $2.58 \pm 1.26$ & $322.00 \pm 166.07$ & $0.43 \pm 0.22^{\mathrm{b}}$ \\
\hline & $>7$ & $46 \pm 1$ & $153.40 \pm 3.21$ & $33.32 \pm 0.82$ & $9.56 \pm 2.30$ & $6.90 \pm 2.29$ & $1.13 \pm 0.40$ & $1.98 \pm 0.45$ & $373.20 \pm 96.96$ & $0.60 \pm 0.14$ \\
\hline \multirow{3}{*}{ 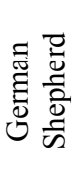 } & $1-2$ & $48 \pm 4$ & $158.00 \pm 11.25$ & $33.23 \pm 0.31$ & $13.33 \pm 1.67$ & $7.70 \pm 1.00$ & $2.70 \pm 0.89$ & $2.93 \pm 0.28$ & $388.50 \pm 56.04$ & - \\
\hline & $2-7$ & $49 \pm 5^{\mathrm{a}}$ & $166.82 \pm 19.00^{\mathrm{a}}$ & $34.18 \pm 1.70$ & $10.97 \pm 2.62$ & $7.21 \pm 2.45$ & $1.69 \pm 0.70$ & $2.27 \pm 0.78$ & $343.85 \pm 104.22$ & $0.35 \pm 0.15^{\mathrm{a}}$ \\
\hline & $>7$ & $45 \pm 4$ & $154.11 \pm 13.06$ & $34.21 \pm 1.20$ & $10.19 \pm 2.23$ & $6.57 \pm 2.03$ & $4.56 \pm 7.73$ & $2.28 \pm 1.06$ & $307.44 \pm 122.98$ & $0.33 \pm 0.12$ \\
\hline \multirow{3}{*}{$\begin{array}{l}\ll \\
\vdots \\
z \\
z\end{array}$} & $1-2$ & 0.333 & 0.398 & 0.292 & 0.501 & 0.940 & 0.063 & 0.256 & 0.614 & - \\
\hline & $2-7 \stackrel{\dot{0}}{\ddot{n}}$ & $0.000^{*}$ & $0.000^{*}$ & 0.093 & 0.286 & 0.137 & 0.219 & 0.392 & 0.478 & $0.003^{*}$ \\
\hline & $>7$ & 0.715 & 0.852 & 0.363 & 0.490 & 0.701 & 0.285 & 0.500 & 0.606 & 0.591 \\
\hline
\end{tabular}

${ }^{*}$ Statistically significant difference between dog breeds and age.

${ }^{\mathrm{ab}}$ Values in the same column for the same parameter which does not contain common letter mark have present statistical differencies.

The highest average concentration of hemoglobin was observed in German Shepherd dog $(166.82 \pm 19.00 \mathrm{~g} / \mathrm{l})$ during $2-7$ years age. Statistical analysis (ANOVA) of compared parameteres between age groups, from 2 to 7 years, showed significance difference of packed cell volume ( $p=$ $0.00)$, hemoglobin concentration $(p=0.00)$ and reticulocytes $(p=0.003)$. PostHoc test showed statistically significant differencies for PCV, hemoglobin concentration and reticulocytes only for 
dogs from 2 to 7 years between Malinois and German Shepherd and between Labrador Retriever and Malinois dogs.

Stress reactions, including physical exercise, can cause changes in behavior and cardiovascular and endocrine system. This physiological systems are involved in the stress responses: sympathetic adrenal medullary axis (SAM) which stimulates adrenal medulla to secrete adrenaline and noradrenaline in small dose during psychological stress. Experimental-induced activation of SAM system in dogs causes increased level of catecholamines (Engeland et al. [7]), antidiuretic response (Koepke et al. [8]), and cardiovascular changes. Any changes, as stress or training, can provoke mechanisms of physiological adaptations, especiallly energy-depended aerobic adaptation. Intensive dogs training, certainly causes increased energy requirements, which can cause changes in number of red blood cells and hemoglobin concentration. One study reported higher number of red blood cells, values of packed cell volume and hemoglobin concentration in male training dogs, but others reports observed no differences between the sexes (Harper et al. [9]). The analysis of hematological parameters in our research showed individual variations between different breeds and all parameters were in reference ranges. The analysis of hematological and biochemical parameters are used for determination of this changes and their values, if they are in correlation with intensity of metabolic reactions in organism. Hematological parameters can give informations about energetic changes and metabolic requirements of organism, as well as informations about patological conditions. Training exercises increases energetic demands which affects the number of red blood cells and hemoglobin concentration, while pathological changes can lead the changes in number of white blood cells. All hematological results were obtained in the reference range, but some differenes were noticed during analyzing individual values of hematological parameters. The largest number of analyzed dogs were between 2 and 7 years old. Statistical significant differencies were obtained for packed cell volume values, hemoglobin concentration and reticulocytes. Reticulocytes suggest the production rate and maturation of red blood cells and the number was associated with increased aerobic demands. In this case, increased values of red blood cells would be present as well. Changes in hemoglobin concentration are in correlation with the changes of red blood cells values and PCV. The highest concentrations of hemoglobin are obtained in German
Shepherd dogs which confirms the way that they are properly trained. German Shepherd dog has a very high value of certain biochemical parameters, such as glucose, cholesterol and triglycerides, indicating a higher metabolic rate than other two breeds. German Shepherds analysis of hematological parameters revealed no significant difference in $\mathrm{RBC}, \mathrm{WBC}, \mathrm{Hb}, \mathrm{MCV}, \mathrm{MCH}, \mathrm{MCHC}$ and differential leukocytes counts between adults and juveniles (Shadia [10]). Increased metabolic rate can be correlated with oxidative metabolism. The PCV, $\mathrm{Hb}$ and WBC did not differ significantly between German Shepherd and local stray dogs in research reported by Ariyibi et al. [11]. The values of parameters obtained in this study, were consistent with earlier reports for tropical dogs (Awah \& Nottidge [12]), but slightly lower than values reported for temperate dogs (Bush [13]). Comparing our hematological parameters with other breeds, is understandable why hemoglobin concentration and packed cell volume were higher than the other two breeds. Comparing hematological parameters between Malinois and Labrador Retriever, there were similarity of results between them. These variations could be results of genetic predisposition and other exogen and endogen factors, such as duration of training, metabolism level and general physical condition. Variations in biochemical parameters are also described by Swanson et al. [14] who reported that these parameters depends by nutrition. Equable values of hemoglobin concentration and MCHC indicates well trained dogs, while the variation of white blood cells may be associated with processes such as training, hormone level, metabolism, stress and diet. Decreased number of lymphocytes by aging was reported and this data was lower compared with other researches (Khan et al. [15]). The changes in hematological parameters as well as significant differences in hemoglobin concentration and reticulocyte number are the result of aerobic demands due to intense training.

Hemoglobin concentrations in Labrador Retriever dogs were lower, while the lymphocytes, neutrophils and eosinophils were very high compared with data of Kayar et al. [16]. Intense work increases energetic metabolism and due to that fact it is expected that the number of red blood cells, and consequently the concentration of haemoglobin, will be increased. Evaluation of sporting dogs for exercise intolerance can be performed by analyzing hematological parameters and their values for each type of exercise. Responses of the dog organism can varies according type and duration of 
performed excercise (Jari et al. [17]). Higher values of leukocytes and lower values of hemoglobin compared into dogs breeds exposed to hard training were also evident in Labrador Retriever dogs, reported by Matwichuk et al. [18]. Intense physical training induce increase aerobic metabolism rate. The significant high values of hemoglobin concentration and red blood cells after the breed were obtained in beagle dogs (Lund et al. [19]). Inadequate energy intake may contribute to reduced weight with changing endocrine homeostasis (McKenzie et al. [20]). Tukey test showed that the differences were evident in hematological values, determined in two dogs breeds (Labrador Retriever and German Shepherd).

It is observed that different dog breeds achieve stabile aerobic metabolism after precise evaluation. Well trained dogs do not show significant deviation of hematological parameters in comparision to dogs who are not exposed to intensive training. Optimal age for intensive trainings is from two to seven years. Hemoglobin concentration, values of MCHC and number of reticulocytes can be consider as physical conditional and fitness. These three parameters show that German Shepherd dog can perform very intensive training compared to Malinois or Labrador Retriever.

\section{REFERENCES}

[1] Rovira, S., Munoz, A., Benito, M.: Effect of exercise on physiological, blood and endocrine parameters in search and rescue-trained dogs. Vet. Med., 53 (6), 333-346 (2008).

[2] Angle, T. C., Wakschlage, J., Gillette, R. L., Stokol, L., Geske, S., Adkins, T. O., Gregor, C.: Hematological, serum biochemical and cortisol changes associated with anticipation of exercise and short duration high intensity exercise in sled dogs. Vet. Clin. Path., 8, 370-374 (2009).

[3] Otto, C. M., Downend, A. B., Serpell, J. A., Ziemer, L. S., Saunders, H. M.: Medical and behavioral surveillance of dogs deployed to the World Trade Center and the Pentagon from October 2001 to June 2002. J. Am. Vet. Med. Assoc., 225 (6), 861-867 (2004).

[4] Foreman, J. H., Bayly, W. M., Grant, B. D., Gollnick P. D.: Standardized exercise test and daily heart rate responses of thorough breds undergoing conventional race training and detraining. Am. J. Vet. Res., 51, 914-920 (1990).

[5] Cannon, W. B., De La Paz D.: The stimulation of renal secretion by emotional excitement. J. Am. Med., 4, 742 (1911).

[6] Jensen, A. L., Aaes, H.: Critical differences of clinical chemical parameters in blood from dogs. Res. Vet. Sci., 1, 10-14 (1993).
[7] Engeland, W. C., Miller, P., Gann, D. S.: Pituitaryadrenal adrenomedullary responses to noise in awake dogs. Am. J. Physiol., 258, 672-677 (1990).

[8] Koepke, J. P., Light, K. C., Obrist, P. A.: Neural control of renal excretory function during behavioral stress in conscious dogs. Am. J. Physiol., 245, 251-258 (1983).

[9] Harper, E. J., Hackett, R. T., Wilkinson, J., Heaton, P. R.: Age-related variations in hematologic and plasma biochemical test results in Beagles and Labrador Retrievers. J. Am. Vet. Med. Assoc., 223, 1436-1442 (2003).

[10] Shadia, A. O.: Normal values of some serochemical parameters in male and female German Shepherds dogs in Sudan. Assiut. Vet. Med., 55 (120), 110-115 (2009).

[11] Ariyibi, A. A., Oyeyemi, M. O., Jadi, R. A.: A comparative study of some hematology and biochemical parameters of clinically healthy alsatian and local dogs. S. Afr. J. Biomed. Res., 5, 145-147 (2000).

[12] Awah, A., Nottidge, H. O.: Serum biochemical parameters in clinically healthy dogs in Ibadan. Trop. Vet., 16, 123-129 (1998).

[13] Bush, B. M.: Interpretation of Laboratory: Results for Small Animal, Clinician Blackwell Scientific Publication, London, 1991.

[14] Swanson, K. S., Kuzmuk, K. N., Schook, L. B., Fahey, J. R: Diet affects nutrient digestibility, hematology, and serum chemistry of senior and weanling dogs. J. Anim. Sci., 2, 1713-1724 (2004).

[15] Khan, S. A., Epstein, J. H., Olival, K. J., Hassan, M. M., Hossain, M. B., Rahman, K. B. M. A., Elahi, M. F., Mamun, M. A., Haider, N., Yasin, G., Desmond, J.: Hematology and serum chemistry reference values of stray dogs in Bangladesh. O. Vet. J., 1, 13-20 (2011).

[16] Kayar, A., Or, M. E., Gönür, E., Akdenezili, Ç., Bakirel, P. U., Dodurka, H. T.: Von Willebrand's disease in German shepherd dogs in the Marmara region (Turkey), Rev. Méd. Vét., 157 (1), 11-15 (2006).

[17] Jari, A., Miettinen, P. V. A., Saamanen, A. M., Haapanen, K., Parviainen, M., Tammi, M., Helminen, H. J.: Effect of aerobic long distance running training (up to $40 \mathrm{~km} \times$ day) of 1-year duration on blood and endocrine parameters of female beagle dogs. Eur. J. Appl. Physiol., 67, 321-329 (1993).

[18] Matwichuk, C. L., Taylor, S. M., Shmon, C. L., Kass, P. H., Shelton, G. D.: Changes in rectal temperature and hematologic, biochemical, blood gas, and acid-base values in healty Labrador Retrievers before and after strenuous exercise. Am. J. Vet., 60 (1), 88-92 (1999).

[19] Lund, C., Kuhl, S., Mischke, R., Günzel-Apel, A. R.: Reference values of the red blood profile in beagle, German Shepherd and Golden Retriever puppies. Berl. Munch. Tierarztl. Wochenschr., 113 (11-12), 447-53 (2000).

[20] McKenzie, E. C., Jose-Cunilleras, E., Hinchcliff, K. W., Holbrook, T. C., Royer, C., Patyon, M. E., Williamson, K., Nelson, S., Willard, M. D., Davis, M. S.: Serum chemistry alterations in Alaskan sled dogs during five successive days of prolonged endurance exercise. J. Am. Vet. Med. Assoc., 230, 1486-1492 (2007). 


\section{List of abbreviations:}

EDTA - Ethylenediaminetetraacetic acid,

PCV - Packed cell volume,

$\mathrm{Hb}$ - Hemoglobin,

$\mathrm{MCHC}$ - Mean corpuscular hemoglobin concentration,

WBC - Leukocytes,
NEU - Neutrophils,

EOS - Eosinophils,

LYM - Lymphocytes,

RET - Reticulocytes,

PLT - Platelets,

Sig. - Significance. 